\title{
Risk of suicide among users of calcium channel blockers: population based, nested case-control study
}

\author{
Christiane Gasse, Laura E Derby, Catherine Vasilakis, Hershel Jick
}

Lindberg et al reported the results of two studies, which they interpreted as showing that calcium channel blockers may increase the risk of suicide. ${ }^{1}$ They found a significant correlation between rates of suicide and use of calcium channel blockers $(r=0.29$, $\mathrm{P}<0.001)$ in a cross sectional ecological study and an increased risk of suicide (relative risk 5.4, 95\% confidence interval 1.4 to 20.5) in users of calcium channel blockers compared with non-users. But they did not control for important independent risk factors such as depression and did not validate diagnoses of suicide.

We aimed at investigating further the possible association between use of calcium channel blockers and risk of suicide among people with hypertension, given the limitations of Lindberg et al's study. ${ }^{2}$

\section{Subjects, methods, and results}

The study was based on information derived from the General Practice Research Database. ${ }^{3}$ The database has been shown to record suicides reliably. ${ }^{4}$ We identified 153458 patients with hypertension who had received a prescription for an antihypertensive drug between January 1991 and August 1998. This base population formed the cohort for a nested casecontrol study.

We identified 46 subjects among the base population who committed suicide (Oxford Medical Information System code 3009D) between January 1991 and August 1998. The date of death was considered to be the index date. Cases had to have been currently exposed to one of the exposures of interest: a calcium channel blocker (with or without a diuretic or a $\beta$ blocker) or any other antihypertensive drug alone or in combination ( $\beta$ blockers, angiotensin converting enzyme inhibitors, diuretics, other (methyldopa, vasodilators, $\alpha$ blockers)). Current exposure was defined as a prescription for antihypertensive $\operatorname{drug}(\mathrm{s})$ within the six months before the index date. Seven patients had not received such a prescription within this period and were therefore excluded. One patient was excluded because of illicit drug use.

We then identified 140 controls who were currently being treated with an antihypertensive drug; they were matched to the 38 cases for age, sex, practice, and index date. Altogether, $161(90 \%)$ cases and controls received a prescription for an antihypertensive drug within the three months before the index date, and 157 had received antihypertensive treatment of any kind for at least one year. The age and sex distributions were similar in cases and controls because of matching. Thirty two $(84 \%)$ cases were over 60 and $32(84 \%)$ were male.

We conducted conditional logistic regression analysis, adjusting for body mass index (weight $(\mathrm{kg}) /\left(\right.$ height $\left.\left.(\mathrm{m})^{2}\right)\right)$, smoking, and history of mental illness. The adjusted relative risk estimate for suicide was 0.98 (0.30 to 3.18) for users of calcium channel blockers compared with users of other antihypertensive drugs (table). We found an independent increased risk of 15.7 (5.4 to 45.8) for suicide associated with a history of mental illness and a protective effect for body mass index $\geqslant 25$ (relative risk $0.33,0.11$ to 0.98 ). The restriction in the analysis to subjects who were exposed within the three months before the index date

\section{Comment}

We did not find an increased risk of suicide associated with use of calcium channel blockers compared with use of other antihypertensive drugs. Because of the relatively small number of cases and wide confidence intervals, however, we cannot rule out some effect of the drugs on the risk of suicide.

We thank the participating general practitioners for their help. Contributors: $\mathrm{CG}$ and $\mathrm{HJ}$ had the original idea and designed the study. CV and LED were involved in the analysis and writing the paper. CG and $\mathrm{HJ}$ will act as guarantors for the paper.

Funding: The Boston Collaborative Drug Surveillance Program is partly supported by grants from AstraZeneca, Bayer AG, Berlex Laboratories, Boots Healthcare International, Bristol-Myers Squibb, GlaxoWellcome, Hoffman-La Roche, RW Johnson Pharmaceutical Research Institute, McNeil Consumer Products, and Novartis Pharmaceuticals. This study was not directly funded by any of these companies. CG is a research fellow supported by a grant from Paul-Martini Stiftung, Bonn, Germany.

Competing interests: None declared.

1 Lindberg G, Bingefors K, Ranstam J, Rastam L, Melander A. Use of cal cium channel blockers and risk of suicide: ecological findings confirmed in population based cohort study. BMJ 1998;316:741-5.

2 Bergman U, Isacsson G. Use of calcium channel blockers and risk of suicide. BMJ1998:317:1076.

3 Jick H, Jick SS, Derby LE. Validation of information recorded on general practitioner based computerised data resource in the United Kingdom. BMJ 1991;302:766-8.

4 Derby LE, Jick H, Dean AD. Antidepressant drugs and suicide. J Clin Psychopharmacol 1992;12:235-40.

(Accepted 11 November 1999)

Crude and adjusted ${ }^{\star}$ estimates of relative risk of suicide

\begin{tabular}{|c|c|c|c|c|}
\hline & \multirow{2}{*}{$\begin{array}{c}\text { No }(\%) \text { of } \\
\text { cases } \\
(\mathrm{n}=38)\end{array}$} & \multirow{2}{*}{$\begin{array}{l}\text { No }(\%) \text { of } \\
\text { controls } \\
(\mathrm{n}=140)\end{array}$} & \multicolumn{2}{|c|}{ Estimate of relative risk $(95 \% \mathrm{Cl})$} \\
\hline & & & Crude & Adjusted \\
\hline $\begin{array}{l}\text { Taking other antihypertensive } \\
\text { drugs† }\end{array}$ & $29(76)$ & $107(76)$ & 1.0 & 1.0 \\
\hline $\begin{array}{l}\text { Taking calcium channel } \\
\text { blockers }\end{array}$ & 9 (24) & $33(24)$ & 1.01 (0.41 to 2.49 ) & 0.98 (0.30 to 3.18$)$ \\
\hline
\end{tabular}

Body mass index:

\begin{tabular}{|c|c|c|c|c|}
\hline$<25 \dagger$ & $11(29)$ & $25(18)$ & 1.0 & 1.0 \\
\hline$\geqslant 25$ & $13(34)$ & $64(46)$ & 0.50 (0.20 to 1.22$)$ & 0.33 (0.11 to 0.98 ) \\
\hline Unknown & $14(37)$ & $51(36)$ & 0.60 (0.21 to 1.71$)$ & 0.67 (0.17 to 2.63 ) \\
\hline \multicolumn{5}{|l|}{ Smoking status: } \\
\hline $\begin{array}{l}\text { Non-smoker or former } \\
\text { smokert }\end{array}$ & $23(61)$ & $99(71)$ & 1.0 & 1.0 \\
\hline Cigarette smoker & 7 (18) & $14(10)$ & $2.10(0.75$ to 5.85$)$ & 1.30 (0.31 to 5.36$)$ \\
\hline Unknown & $8(21)$ & 27 (19) & $1.40(0.40$ to 4.97$)$ & 1.30 (0.23 to 7.33$)$ \\
\hline \multicolumn{5}{|l|}{ History of mental illness: } \\
\hline No† & $13(34)$ & $121(86)$ & 1.0 & 1.0 \\
\hline Yes & $25(66)$ & 19 (14) & 13.04 (4.89 to 34.80 ) & 15.70 (5.37 to 45.80 \\
\hline
\end{tabular}

${ }^{*}$ Adjusted for all other covariates simultaneously. †Reference group.

\section{Boston \\ Collaborative Drug \\ Surveillance \\ Program, Boston \\ University School of \\ Medicine, \\ Lexington, MA \\ 02421, USA \\ Christiane Gasse \\ pharmacoepidemiologist \\ Laura E Derby \\ assistant professor of \\ public health \\ Catherine Vasilakis \\ pharmacoepidemiologist \\ Hershel Jick \\ associate professor of \\ medicine \\ Correspondence to: \\ C Gasse \\ cgasse@bu.edu}

\section{BMJ 2000;320:1251} did not change the results. 